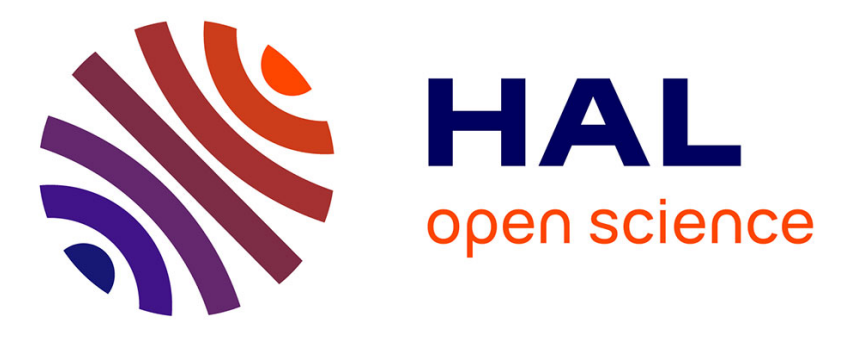

\title{
From spatial-continuous electrical resistivity measurements to the soil hydraulic functioning at the field scale
}

Isabelle I. Cousin, Arlène Besson, Hocine Bourennane, Catherine Pasquier, Bernard B. Nicoullaud, Dominique D. King, Guy Richard

\section{To cite this version:}

Isabelle I. Cousin, Arlène Besson, Hocine Bourennane, Catherine Pasquier, Bernard B. Nicoullaud, et al.. From spatial-continuous electrical resistivity measurements to the soil hydraulic functioning at the field scale. Comptes Rendus Géoscience, 2009, 341 (10-11), pp.859-867. 10.1016/j.crte.2009.07.011. hal-02662218

\section{HAL Id: hal-02662218 \\ https://hal.inrae.fr/hal-02662218}

Submitted on 30 May 2020

HAL is a multi-disciplinary open access archive for the deposit and dissemination of scientific research documents, whether they are published or not. The documents may come from teaching and research institutions in France or abroad, or from public or private research centers.
L'archive ouverte pluridisciplinaire HAL, est destinée au dépôt et à la diffusion de documents scientifiques de niveau recherche, publiés ou non, émanant des établissements d'enseignement et de recherche français ou étrangers, des laboratoires publics ou privés. 
Version définitive du manuscrit publié dans / Final version of the manuscript published in :

Comptes Rendus Géoscience, 2009, 341(10-11), 859-867, http://dx.doi.org/10.1016/j.crte.2009.07.011

\section{From spatial-continuous electrical resistivity measurements to} the soil hydraulic functioning at the field scale.

Isabelle Cousin ${ }^{1}$, Arlène Besson ${ }^{1,2}$, Hocine Bourennane ${ }^{1}$, Catherine Pasquier ${ }^{1}$, Bernard Nicoullaud $^{1}$, Dominique King ${ }^{1}$, Guy Richard ${ }^{1}$

${ }^{1}$ INRA, UR0272 Science du Sol, Centre de recherche d'Orléans, CS40001 Ardon, 45075 Orléans cedex 2, France

${ }^{2}$ Department of Environmental Sciences and Land Use planning, Université Catholique de Louvain, Croix du Sud 2 box 2, 1348 Louvain-la-Neuve, Belgium

Corresponding author: Isabelle.Cousin@ orleans.inra.fr

Phone: (+33) 238414803

Fax: (+33) 238417869

Keywords: digital soil functioning mapping - field scale - soil water content - soil water potential - DC geophysical method 


\begin{abstract}
The aim of this paper was to present a strategy to interpret the hydraulic functioning of a small field area by using measurements of the soil electrical resistivity. The spatial soil electrical resistivity was recorded at a high resolution on a 2 ha area by the MuCEP device (MultiContinous Electrical Profiling) at two dates. These apparent electrical resistivity measurements were firstly interpreted in terms of local electrical resistivity by 1D inverse modelling to estimate the real resistivity of the soil. These interpreted electrical resistivity data were then transformed into soil water content values and soil water potential values by the use of independent punctual data of water content and the use of the water retention curve determined by laboratory data.

Our analysis has permitted to describe the spatial variability and temporal evolution of the hydraulic functioning at high resolution from electrical resistivity data. The interpretation of the water content and matric potential maps demonstrated that some soil hydraulic processes, like lateral overland flow, can occur in the studied zone. They would never have been detected by local measurements of soil characteristics or by the use of the soil map.
\end{abstract}

\title{
Résumé
}

Ces travaux ont pour objectif de proposer une stratégie permettant de discuter du fonctionnement hydrodynamique des sols à l'échelle parcellaire à partir de mesures spatiales de la résistivité électrique. Celle-ci a été mesurée à deux dates, sur une parcelle de 2 ha, à l'aide du MuCEP (MultiContinous Electrical Profiling). Ces mesures électriques ont été analysées localement par un modèle 1D de façon à estimer la résistivité vraie du sol, puis les données de résistivité vraie ont été interprétées en termes de teneur en eau et de potentiel matriciel, à l'aide de mesures ponctuelles de teneur en eau et de la courbe de rétention des sols étudiés déterminée de façon indépendante au laboratoire. Cette analyse a permis de décrire la distribution spatiale et l'évolution temporelle de la teneur en eau du sol à haute résolution. L'interprétation des cartes de teneur en eau et de potentiel matriciel met en évidence certains processus hydrodynamiques, tels que des écoulements latéraux hypodermiques. Ceux-ci n'auraient pu être détectés par des mesures ponctuelles de teneur en eau, et n'auraient pu être inférés à partir de la carte des sols de la parcelle. 
Version définitive du manuscrit publié dans / Final version of the manuscript published in :

Comptes Rendus Géoscience, 2009, 341(10-11), 859-867, http://dx.doi.org/10.1016/j.crte.2009.07.011

\section{Introduction}

In the context of precision agriculture, the understanding of the soil hydraulic functioning at a high spatial resolution is required for adapting the water supplies to the plants demand, whatever the position in the field. To describe the spatial hydraulic functioning, one can analyse the temporal evolution of the spatial distribution of the water content, or, better of the water potential. The initial problem is then to provide a way of producing a map of the water content.

A first way consists in using punctual measurements of the water content, that are then interpolated. The quality of the estimated map depends on the sampling density of the water content measurements. Usually the latter are scarce because they are destructive and timeconsuming.

A second way is to use ancillary data to provide some informations on the soil properties. Such data include yield from yield monitors, digital information from aerial photographs, electromagnetic induction data, elevation, and so on $[3 ; 4 ; 5 ; 7 ; 17 ; 18 ; 23 ; 24]$. They are usually more intensive, and less expensive to obtain than the soil properties. Among these ancillary data, we focus here on the measurements from electrical resistivity sensors whose use is becoming more widespread in surveys for land management. The apparent electrical resistivity of the soil is related to several soil physical properties, and especially the moisture content: a wetter soil is more electrically conductive than a drier soil $[11 ; 16]$. Previous works have shown the value of the electrical resistivity to assess the soil water content $[6 ; 21]$. Thanks to the MuCEP device (MultiContinuous Electrical Profiling), exhaustive spatial measurements of the electrical resistivity can be recorded with a high resolution [8]. A map of the electrical resistivity can then be used as an external drift in the kriging procedure to map of water content from punctual measurements. Bourennane et al. [6] showed that the estimated map of water content is of better quality than the one produced without the use of the electrical resistivity.

A third way to analyse the spatial hydraulic functioning of soil is to describe the temporal variability of the electrical resistivity between several maps taken at different dates. If the maps have been corrected from the effects of the temperature - that strongly influences the electrical resistivity measurements - the differences between these maps can only result from the evolution of the water content, once we have checked that the composition of the soil solution is not a first-order parameter that influences the electrical resistivity. Using that way, Besson et al. [2] showed that the temporal evolution of the water content at the field scale can be predicted by the analysis of the temporal evolution of electrical resistivity data. 


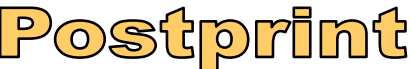

Version définitive du manuscrit publié dans / Final version of the manuscript published in :

Comptes Rendus Géoscience, 2009, 341(10-11), 859-867, http://dx.doi.org/10.1016/j.crte.2009.07.011

A fourth way to use the information about water content included in the electrical resistivity signal, would be to interpret the apparent resistivity data into real resistivity data and to determine the water content by using a model of the relationship between the real resistivity and the water content. The latter could then be interpreted in terms of matric potential if we know the water retention curve of the studied soil horizon. This paper aims at testing this method of providing maps of the soil water content and soil matric potential by using scarce measurements of the water content and maps of the apparent electrical resistivity. 
Version définitive du manuscrit publié dans / Final version of the manuscript published in :

Comptes Rendus Géoscience, 2009, 341(10-11), 859-867, http://dx.doi.org/10.1016/j.crte.2009.07.011

\section{Material and methods}

\subsection{General sketch of the study}

From the spatial electrical resistivity measurements to the spatial estimation of the water potential, our study consisted of 4 steps (Fig. 1):

1. The apparent electrical resistivity was measured at 3 pseudo-depths by the MuCEP device at the field scale at two dates during the year 2006 (see paragraph 2.3).

2. The apparent resistivity data were modelled by $1 \mathrm{D}$ inverse modelling to produce a true resistivity map that represents the spatial distribution of the resistivity of a specific soil layer (see paragraph 2.4). The interpreted resistivity data were then corrected for the temperature effect by the Keller and Frischknecht equation [12], so that the resistivity measurements obtained at the 2 dates could be compared.

3. The interpreted resistivity map was transformed into a map of water content by using an empirical relationship between electrical resistivity and water content. This relationship was determined from field measurements during one year of both the electrical resistivity - by electrical tomography (ERT) - and the soil water content, by TDR probes (see paragraph 2.5).

4. Finally, the water content map was interpreted in terms of water potential thanks to a water retention curve. The latter was determined by laboratory measurements and expressed according to the van Genuchten equation (see paragraph 2.6). It is really important to use the data up to this stage, and not to stop the analysis on the $3^{\text {rd }}$ stage. Indeed, the evolution of the water content alone does not help in interpreting the hydraulic functioning, say the drying or wetting processes in the soil, or the infiltration versus runoff processes.

\subsection{Characteristics of the studied area}

The study site was located in the Beauce region (France), on a fallow field of 2 ha. The soils consisted in a loamy-clay layer developed over the Beauce limestone bedrock or the cryoturbed or soft limestone deposits. They were haplic or calcaric cambisols [9] and were classified into several units according to both the bedrock in which they have developed, and the thickness of the loamy-clay layer. Thirty-three auger holes were digged to i) describe the different soil horizons, ii) define the thickness of the loamy clay-layer and iii) measure the gravimetric water content in each soil horizon. To describe the evolution of the soil water content at the field scale, this sampling was done twice: the $12^{\text {th }}$ of April 2006 and the $1^{\text {st }}$ of June 2006. From the analysis of the soil in the auger holes, 8 soil units were defined on a soil map (Fig. 2a). The thickness of the loamy-clay layer was determined on the whole studied 
Version définitive du manuscrit publié dans / Final version of the manuscript published in :

Comptes Rendus Géoscience, 2009, 341(10-11), 859-867, http://dx.doi.org/10.1016/j.crte.2009.07.011

surface area by ordinary kriging. It varied from $0.3 \mathrm{~m}$ (very shallow soils developed on the South-East part of the studied zone) to $0.85 \mathrm{~m}$ (deep soils in the North-West part of the studied area) (Fig. 2b).

\subsection{Spatial monitoring of the electrical resistivity at the field scale}

Electrical resistivity measurements were obtained at the field scale by the use of MuCEP device $[2 ; 8 ; 20]$. The MuCEP device is a mobile soil electrical resistivity mapping system, that comprises a multi-probe system of 3 arrays (V1, V2, V3 arrays) pulled by a cross-country vehicle. The distance between the current injection electrodes and the resistivity measurement electrodes is equal to $0.5 \mathrm{~m}$ for the V1 array, $1 \mathrm{~m}$ for the V2 array and $2 \mathrm{~m}$ for the V 3 array. This system is completed by a resistivity meter $(10 \mathrm{~mA}, 122 \mathrm{~Hz})$ and a Doppler radar which triggers a measurement every $0.1 \mathrm{~m}$ along an electrical transect. The electrical measurements consist in apparent resistivity measurements for 3 pseudo-depths. All measurements were georeferenced and recorded on a PC. The electrical resistivity measurements with the MuCEP system were recorded at the same dates as the characterisation by the auger holes, say the $12^{\text {th }}$ of April and the $1^{\text {st }}$ of June 2006. At each date and for each array, a minimum of 52000 measurements were recorded.

\subsection{Inversion of the apparent resistivity data recorded by the MuCEP device.}

For each date, the electrical resistivity of the loamy-clay layer was modelled from the 3 sets of apparent electrical resistivity measurements by a 1D inverse modelling. The QWIN1D software was used. It was developed at the University of Paris VI (France) and used the Levenberg-Marquadt optimisation algorithm. The inverse process was constrained by (1) a conceptual model of the electrical resistivity distribution on the vertical plan and (2) the loamy-clay layer thickness. The conceptual model consisted of two layers with a contrasted electrical resistivity: the loamy-clay layer with a resistivity (parameter1) equal to $\sim 30 \mathrm{ohm} . \mathrm{m}$ in April and $\sim 70$ ohm.m in June, and the limestone bedrock with a resistivity (parameter2) equal to $\sim 400 \mathrm{ohm} . \mathrm{m}$. These electrical resistivity values were chosen from the analysis of 2D electrical resistivity tomographies (ERT) realised at two different locations in the studied area (Fig. 2b). From the thickness of the loamy-clay layer determined from the 33 auger holes, the studied area was divided into 12 parts for which the thickness of the loamy-clay layer could be considered as constant. For each part, the inverse process was conducted independently: the thickness of the loamy-clay layer was fixed and the electrical resistivities of the loamyclay layer and of the limestone bedrock were calculated and optimised from the initial values 
Version définitive du manuscrit publié dans / Final version of the manuscript published in :

Comptes Rendus Géoscience, 2009, 341(10-11), 859-867, http://dx.doi.org/10.1016/j.crte.2009.07.011

mentioned above. The electrical resistivity of the loamy-clay layer was then corrected for the temperature effect by the Keller and Frischknecht equation [13] at a reference temperature equal to $25^{\circ} \mathrm{C}$.

\subsection{Local monitoring of the electrical resistivity and of the water content}

To determine the field relationship between the electrical resistivity and the water content, a 2D electrical resistivity tomography (ERT) experiment was conducted once a week during the year 2006, at two locations on the studied area (Fig. 2.b). The electrical resistivity measurements were made using a Syscal R1 Plus resistivity meter and a switch module (Iris Instrument, France) connected to 32 electrodes spaced $0.2 \mathrm{~m}$ apart, in Wenner Alpha array, as a good compromise between spatial resolution and sensitivity to noise. The electrical tomographies were always located at the same position in the field. The smoothnessconstrained inversion of the data sets was achieved using a time lapse inversion technique by using the Res2DInv software [14, 15]. The same background model as mentioned in paragraph 2.4 was used to constrain the inverse process. We have determined then the real electrical resistivity of the loamy-clay layer at each date of the measurement and at different depths along the soil profile. These data were corrected for the temperature effect by the Keller and Frischknecht equation [12] at a reference temperature equal to $25^{\circ} \mathrm{C}$. Calibrated TDR probes were installed near the site of the electrical tomographies and the water content was recorded at different depths of the loamy-clay layer $(-12,-15,-20,-34,-40 \mathrm{~cm}$ depth) at each date of the electrical tomographies measurements. Mean values of electrical resistivity and water content were calculated for the loamy-clay layer. We decided to work on mean values because of statistical dispersion of electrical data. These last resulted from field experiments and could be noise because of soil structural heterogeneities (fauna activity, cracks in summer). Mean values enabled to smooth such variability. Thanks to these data, an empirical relationship between the field electrical resistivities and the field water contents was determined. As demonstrated in the figure 3, it consisted in a logarithmic decreasing curve; its determination coefficient was equal to 0.85 that indicated the robustness of this empirical law on the studied area.

\subsection{Determination of the water retention curve of the loamy-clay layer}

The relationship between the water content and the water potential was determined by laboratory measurements on small undisturbed loamy-clay clods sampled in the studied area, about $5 \mathrm{~cm}^{3}$ in size. Each soil aggregate was first saturated and then equilibrated at a given 


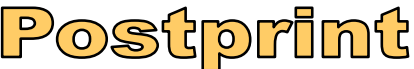

Version définitive du manuscrit publié dans / Final version of the manuscript published in :

Comptes Rendus Géoscience, 2009, 341(10-11), 859-867, http://dx.doi.org/10.1016/j.crte.2009.07.011

water potential for 5 days, until it reached equilibrium [13]. The mass and volumetric water content were then determined after the aggregate was dried at $105^{\circ} \mathrm{C}$ for 24 hours. The volumetric water content was determined on 12 aggregates for 8 values of water potentials: $10 \mathrm{hPa}$; - $33 \mathrm{hPa} ;-100 \mathrm{hPa} ;-330 \mathrm{hPa} ;-1000 \mathrm{hPa} ;-3330 \mathrm{hPa} ;-10000 \mathrm{hPa} ;-15280 \mathrm{hPa}$. From these punctual measurements, a continuous water retention curve was determined according to the model of van Genuchten [22]:

$|h|=\frac{1}{\alpha}\left[\left(\frac{\theta}{\theta_{s}}\right)^{1-1 / n}-1\right]^{1 / n}$

where $h$ represents the water potential $(\mathrm{hPa})$ and $\theta$ the volumetric water content $\left(\mathrm{cm}^{3} . \mathrm{cm}^{-3}\right)$. For the loamy-clay layer of our studied area, the parameters of the van Genuchten equation were the following: $\theta_{\mathrm{s}}=0.42 \mathrm{~cm}^{3} . \mathrm{cm}^{-3} ; \alpha=0.00497 \mathrm{~m}^{-1} ; \mathrm{n}=1.17$. 
Version définitive du manuscrit publié dans / Final version of the manuscript published in :

Comptes Rendus Géoscience, 2009, 341(10-11), 859-867, http://dx.doi.org/10.1016/j.crte.2009.07.011

\section{Results and discussion}

\subsection{Spatial distribution of the apparent and interpreted electrical resistivity data}

For the 2 dates of investigation (12 $2^{\text {th }}$ of April 2006 and the $1^{\text {st }}$ of June 2006), the resistivity of the studied area varied in space at the field scale. For the 2 dates, the mean apparent resistivity value of the V1 array was lower than the value of the V2 array, that was lower than the value of the V3 array (Tab. 1). This was related to the deeper and deeper investigation volume from the V1 array to the V3 array and to the fact that the bedrock was more resistant than the superficial loamy-clay layer. Whatever the date, for the V1 array, the highest apparent resistivity values were observed in the South-East part of the studied area, in the soil unit number 8 (stony calcaric cambisol on hard limestone bedrock) (Fig. 2 c and c'). Intermediate values were observed in the North-West part of the studied area, in the soil unit number 3 (shallow calcaric cambisol on cryoturbed limestone deposit). The lowest values were observed along a corridor from South to North in the middle of the area and in the North part of the studied zone (soil unit number 1, deep haplic cambisol on cryoturbed limestone deposit). Depending on the array (V1, V2 or V3), this spatial organisation was more or less distinct. Whatever the array, the general apparent resistivity of the studied area was lower the $12^{\text {th }}$ of April 2006 than the $1^{\text {st }}$ of June 2006, due to the higher water content in April than in June (Tab. 1).

The resistivity of the loamy-clay layer - determined after inversion from the apparent resistivity data - was highly variable in space (Fig. 2d and 2d', Table 1). In April 2006, the values ranged between 15 ohm.m to 47 ohm.m and in June 2006 they ranged between 26 ohm.m and 99 ohm.m. The spatial organisation was the same for the 2 dates - the highest values in the South-East part, the lowest values in the central zone and intermediate values in the North-West part of the field - and was remarkable for 2 reasons:

- Firstly, this spatial distribution was not exactly the same as the spatial distribution of the apparent resistivity data, which indicated - as expected - that the bedrock had a strong influence on the general value of the apparent electrical resistivity (Fig. $2 \mathrm{~d}$ and $2 \mathrm{~d}$ ').

- Secondly, the spatial distribution of the interpreted resistivity data was not the same as the spatial distribution of the loamy-clay layer thickness: the 2 areas with the lowest thickness of loamy-clay material - say the South-East part and the central part - corresponded respectively to areas with the highest interpreted electrical resistivity data and the lowest interpreted resistivity data. As a consequence, the spatial organisation of the interpreted resistivity data did not result from artefacts of inversion, due to the parameter "thickness of the loamy-clay layer" as it could have been expected. 
Version définitive du manuscrit publié dans / Final version of the manuscript published in :

Comptes Rendus Géoscience, 2009, 341(10-11), 859-867, http://dx.doi.org/10.1016/j.crte.2009.07.011

Whereas the two sources of data (loamy-clay layer thickness and electrical resistivity) do not have the same resolution, the two points mentioned above emphasize the interest of the inversion of spatial electrical resistivity data recorded by the MuCEP device in order to interpret specifically the organisation of the loamy-clay layer.

\subsection{Spatial distribution of the volumetric water content and of the water potential}

From the inverse relationship between the electrical resistivity data recorded by $2 \mathrm{D}$ tomography and the volumetric water content measured by TDR probes (Fig. 3), the map of the interpreted electrical resistivity has been converted firstly into a map of volumetric water content (Fig. 2e and 2e') and secondly into a map of water potential by using the van Genuchten model (Fig. 2f and 2f'). As the electrical resistivity, the water content and water potential presented a specific spatial distribution: for the 2 dates, the highest water content corresponded to the location in the central area of the studied zone. In April, the water content reached a value of $0.33 \mathrm{~cm}^{3} \mathrm{~cm}^{-3}$ that was close to field capacity (Tab.1). Conversely, in June and in the South-East part of the studied area, the water content was low, and reached even values around $0.16 \mathrm{~cm}^{3} \mathrm{~cm}^{-3}$ that corresponded to a water potential higher than the permanent wilting point (Tab. 1). The contrast in terms of water content and water potential was significant for the two dates: indeed, the water content varied from 0.23 to $0.33 \mathrm{~cm}^{3} . \mathrm{cm}^{-3}$ in April whereas it varied from 0.16 to $0.28 \mathrm{~cm}^{3} \cdot \mathrm{cm}^{-3}$ in June (Tab. 1). The water potential was highly contrasted in June, from values close to $2.8(\log \mathrm{hPa})$, to values higher than the permanent wilting point.

The comparison between the soil map and the maps of the volumetric water content and water potential evidenced two statements:

1- the spatial distribution of the soil water content was roughly related to the distribution of soils: the lowest water content corresponded to the shallowest soils in the South-East part of the studied area (soil unit 8), whereas the high values of water content corresponded to the deeper soils in the North part of the studied area (soil units 1 and 2).

2- by carefully looking at the soil map and the map of the water content, one could identify zones where the limits of water content areas did not correspond to limits of the soil units. This was specifically the case in the central part of the studied area: the water content was high and corresponded to four soil types (soil units 1-3-4-5) with deep soils and shallow soils. This central zone had a particular topographical position on the site. It corresponded to the lower elevation in the studied zone and to the sharp limit between the cryoturbed or soft limestone deposits and the hard calcareous bedrock of the South-East part of the field. In the 
Version définitive du manuscrit publié dans / Final version of the manuscript published in :

Comptes Rendus Géoscience, 2009, 341(10-11), 859-867, http://dx.doi.org/10.1016/j.crte.2009.07.011

same way, a zone oriented to the NW-SE in the North part of the area corresponded to lower water contents than the mean water content of this area (Fig. 2e and 2e', see the arrow). It was located on 2 different soil types (soil units 2 and 3) but one can see that it was located on a low topographic position, along a line oriented NW-SE. The water could probably evacuate from this position, either by runoff or by hypodermic transfer, and could accumulate in the neighbouring zones.

As a consequence, the map of the soil types constituted a real basis to describe the soil hydraulic functioning but, even in that region where the water transfer have been demonstrated as being essentially vertical [19], the water could accumulate by lateral transfer. This point is of importance when one would describe the soil system to simulate the water transfer. It should not have been demonstrated without recording the spatial electrical resistivity by the MuCEP device.

\subsection{Discussion about the uncertainty}

From the apparent resistivity data to the water potential, three steps were necessary and could lead to uncertainty in the final results. The general analysis of the uncertainties was not conducted here but we can discuss few points. The uncertainty could have different sources. The first one was the determination of the interpreted resistivity map from apparent electrical resistivity data and the map of the loamy-clay layer thickness. The quality of this step is $a$ priori difficult to evaluate, but one can consider that no abrupt limit can be observed between the different zones that were taken into account for the inversion. Despite the map of the loamy-clay thickness was divided into 12 zones for the inversion, the interpreted resistivity map exhibits continuous shapes without sharp limits, say without any abrupt changes.

The second source of uncertainty could be ascribed to the procedure of calculation of the water content from the electrical resistivity. We have decided to use field data obtained by $2 \mathrm{D}$ tomography at a $0.2 \mathrm{~m}$ resolution for the electrical resistivity and TDR measurements for the water content. This approach was original compared to more classical approaches found in the literature where the water content is estimated from the Archie law $[1 ; 10]$. We decided to derive such empirical relationship because: (1) the Archie law is not valuable for soils with a clay content higher than $15 \%$ as those found in the studied site, and (2) we wanted to avoid discrepancies between laboratory data and field measurements that are commonly observed with electrical resistivity measurements and that are due to the difference of soil volumes that are taken into account. The comparison between the volumetric water content measured in the auger holes during the geophysical prospecting and the water content estimated at the same 


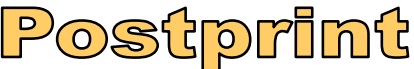

Version définitive du manuscrit publié dans / Final version of the manuscript published in :

Comptes Rendus Géoscience, 2009, 341(10-11), 859-867, http://dx.doi.org/10.1016/j.crte.2009.07.011

points from the interpreted electrical resistivity map demonstrated a good agreement, with a root mean square error equal to $0.02 \mathrm{~cm}^{3} . \mathrm{cm}^{-3}$ (Fig. 4). It validates both the protocol of inversion of apparent electrical resistivity data and the estimation of the water content from the relationship derived from tomography data despite two restrictions: (i) one could expect that the estimation of the water content from electrical resistivity data would not be precise enough for the high water contents, close to saturation; (ii) the main hypothesis for the calculation of the water content from the electrical resistivity consists in the assumption that the loamy-clay layer is homogeneous in texture in the whole studied area. This point has been checked at the location of the auger holes, where the soil was sampled; it could be different at some places.

The third source of uncertainty could be attributed to the procedure of calculation of the water potential from the volumetric water content. To avoid discrepancies between the laboratory and the field measurements due to differences in size of the soil samples, it would probably have been better to measure directly the water potential in the field, during the 2D tomography experiments. Unfortunately, the tensiometers that can be installed in the field do not record water potential values larger than $|-800 \mathrm{hPa}|$. It would not have been sufficient to establish a consistent relationship between the water content and the water potential. At this step, we do not have any tool to validate the transformation of water content into water potential. 


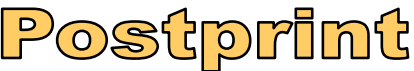

Version définitive du manuscrit publié dans / Final version of the manuscript published in :

Comptes Rendus Géoscience, 2009, 341(10-11), 859-867, http://dx.doi.org/10.1016/j.crte.2009.07.011

\section{Conclusion}

This work consists in a first attempt to evaluate the spatial distribution of the soil water content and the soil water potential at the field scale with a high spatial resolution, without any a priori knowledge of the studied area. From our knowledge, the way to achieve this study, from the field measurements of the electrical resistivity to the validation of the estimation of the water content is original.

In our study case, we have evidenced that the soil map, that is defined from permanent soil characteristics like, for example, the soil texture and the soil structure, is - in a first approximation - a spatial pertinent support to model the soil hydraulic functioning. To precisely describe the water fluxes, the topography has to be taken into account.

This work has been conducted as a demonstration and is supported by the comparison of water soil maps at two dates, both during the desiccation period. It should be completed by other spatial data recorded during the whole hydrologic season, including some periods of wetting and drying. The next step would be to determine the spatial hydrodynamic properties of the soils in the studied area by inverse modelling using the successive maps of soil water content. It would provide a new undisturbed and without a priori method to estimate the spatial soil hydrodynamic properties.

\section{Acknowledgments}

The authors wish to thank P. Courtemanche, A. Dorigny, G. Giot and C. Lelay from the Unité de Science du Sol of INRA Orléans for their assistance during the field experiments. They are grateful to the French programme PNRH for financial support.

\section{List of references}

[1] G.E. Archie, The electrical resistivity $\log$ as an aid in determining some reservoir characteristics, Trans. Am. Inst. Min. Metall. Pet. Eng. 146 (1942) 54-62.

[2] Besson, I. Cousin, H. Bourennane, B. Nicoullaud, C. Pasquier, G. Richard, A. Dorigny, D. King, The spatial and temporal organisation of soil water at the field scale as described by electrical resistivity measurements, European Journal of Soil Science (2008) submitted.

[3] H. Bourennane, D. King, P. Chéry, A. Bruand, Improving the kriging of a soil variable using slope gradient as external drift, European Journal of Soil Science 47 (1996) 473-483. 


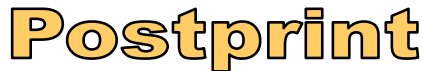

Version définitive du manuscrit publié dans / Final version of the manuscript published in :

Comptes Rendus Géoscience, 2009, 341(10-11), 859-867, http://dx.doi.org/10.1016/j.crte.2009.07.011

[4] H. Bourennane, D. King, Using multiple external drifts to estimate a soil variable, Geoderma 114 (2003) 1-18.

[5] H. Bourennane, C. Dère, I. Lamy, S. Cornu, D. Baize, F. van Oort, D. King, Enhancing spatial estimates of metal pollutants in raw wastewater irrigated fields using a topsoil organic carbon map predicted from aerial photography, Science of the Total Environment 361 (2006) 229-248.

[6] H. Bourennane, D. King, A. Couturier, B. Nicoullaud, B. Mary, G. Richard, Uncertainty assessment of soil water content spatial patterns using geostatistical simulations: an empirical comparison of a simulation accounting for single attribute and a simulation accounting for secondary information, Ecological Modelling 205 (2007) 323-335.

[7] V. Chaplot, C. Walter, P. Curmi, A. Hollier-Larousse, The use of auxiliary geophysical data to improve a soil-landscape model Soil Science 12 (2000) 961-970.

[8] M. Dabas, A. Tabbagh, D. Boisgontier, Multi-depth continuous electrical profiling for characterization of in-field variability, In: 3rd European Conference On Precision Agriculture, June 18th-21st 2001, Montpellier - France (2001).

[9] FAO, World Reference Base for Soil Resources, Rome (2006).

[10] S.P. Friedman, Soil properties influencing apparent electrical conductivity: a review, Computers and electronics in agriculture 46 (2005) 45-70.

[11] D.J. Inman, R.S. Freeland, J.T. Ammons, R.E. Yoder, Soil investigations using electromagnetic induction and ground penetrating radar in Southwest Tennessee, Soil Science Society of America Journal 66 (1) (2002) 206-211.

[12] G.V. Keller \& F.C. Frischknecht, Electrical methods in geophysical prospecting, Pergamon Press Oxford (1966).

[13] Klute, Water retention: Laboratory methods. In: Methods of soil analysis. Part 1. 2nd ed. Agron. Monogr. 9 ASA and SSSA (ed. A. Klute) (1986) pp. 635-662 Madison WI.

[14] M.H. Loke, Time-lapse resistivity imaging inversion, In: 5th Meeting of the Environmental and Engineering Society European, Sept. 6-9 1999, Budapest, Hungary (1999).

[15] M.H. Loke, R.D. Barker, Rapid least square inversion of apparent resistivity pseudosections using a quasi-Newton method, Geophysical Prospecting 44 (1996) 131-152.

[16] D. Michot, Intérêt de la géophysique de subsurface et de la télédétection multispectrale pour la cartographie des sols et le suivi de leur fonctionnement hydrique à l'échelle parcellaire, Thèse Université P. \& M. Curie (2003) 404 p. 


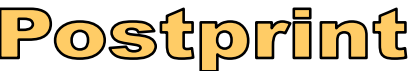

Version définitive du manuscrit publié dans / Final version of the manuscript published in :

Comptes Rendus Géoscience, 2009, 341(10-11), 859-867, http://dx.doi.org/10.1016/j.crte.2009.07.011

[17] T.G. Mueller, F.J. Pierce, Soil carbon maps: enhancing spatial estimates with simple terrain attributes at multiple scales, Soil Science Society of America Journal 67 (2003) 258267.

[18] I.O.A. Odeh, A. Mc Bratney, D.J. Chittleborough, Further results on prediction of soil properties from terrain attributes: heterotopic cokriging and regression-kriging, Geoderma 67 (1995) 215-226.

[19] S. Ould Mohamed, Etude du fonctionnement hydrique hivernal d'un sol limonoargileux de Petite Beauce. Application d'un modèle d'infiltration et incidence sur la lixiviation du nitrate, Thèse de doctorat, Université d'Orléans France (1995).

[20] C. Panissod, M. Dabas, A. Jolivet \& A. Tabbagh, A novel mobile multipole system (MUCEP) for shallow (0-3m) geoelectrical investigation: the 'Vol-de-canards' array, Geophysical Prospecting 45 (1997) 983-1002.

[21] K.R. Sheets, J.M.H. Hendrickx, Non invasive soil water content measurement using electromagnetic induction, Water Resources Research 31 (10) (1995) 2401-2409.

[22] M. Th. van Genuchten, A closed-form equation for predicting the hydraulic conductivity of unsaturated soils, Soil Science Society of American Journal 44 (1980) 892898.

[23] C. Yang, G.L. Anderson, Airborne videography to identify spatial plant growth variability in grain sorghum, Precision Agriculture 1 (1999) 67-79.

[24] R. Zhang, P. Shouse, S. Yates, Use of pseudo-crossvariograms and cokriging to improve estimates of soil solute concentrations, Soil Science Society of America Journal 61 (1997) 1342-1347.

\section{Figure captions}

Figure 1: General sketch of the study.

Figure 1: Démarche générale de l'étude

Figure 2: Spatial pattern of the data recorded and calculated on the studied area. -a- Soil map of the studied area. -b- Map of the loamy-clay layer thickness. -c, c'- Apparent electrical resistivity measurements for the 3 arrays (c: $12^{\text {th }}$ of April 2006; $c^{\prime}: 1^{\text {st }}$ of June 2006). -d, d'Interpreted electrical resistivity for the loamy-clay layer and the bedrock (d: $12^{\text {th }}$ of April 


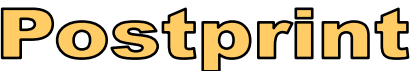

Version définitive du manuscrit publié dans / Final version of the manuscript published in :

Comptes Rendus Géoscience, 2009, 341(10-11), 859-867, http://dx.doi.org/10.1016/j.crte.2009.07.011

2006; $d^{\prime}: 1^{\text {st }}$ of June 2006). -e, e'- Map of the volumetric water content on the studied area (e: $12^{\text {th }}$ of April 2006; e': $1^{\text {st }}$ of June 2006). -f, f'- Map of the water potential on the studied area (f: $12^{\text {th }}$ of April 2006; f': $1^{\text {st }}$ of June 2006).

Figure 2 : Représentation spatiale de l'ensemble des résultats obtenus sur la zone d'étude. - - Carte des sols de la zone étudiée. -b-Carte de l'épaisseur de la couche argilo-limoneuse. -c, c'- Cartes de la résistivité apparente à 3 pseudo-profondeurs (c: 12 Avril 2006; c': $1^{\text {er }}$ Juin 2006). - $d$, $d$ - Cartes de la résistivité interprétée pour la couche argilo-limoneuse et pour le substrat calcaire (d: 12 Avril 2006; d': $1^{e r}$ Juin 2006). -e, e'-Cartes de la teneur en eau volumique (e: 12 Avril 2006; $e^{\prime}: 1^{\text {er }}$ Juin 2006). -f, f'- Cartes du potentiel matriciel (f: 12 Avril 2006; f': $1^{\text {er }}$ Juin 2006).

Figure 3: Relationship between the interpreted electrical resistivity - ERT inverted by the Res2DInv software - and the volumetric water content - recorded by TDR probes- (the locations of the measurements are the stations A and B on the figure $2 b$ ). The number of data is equal to 46 .

Figure 3 : Relation entre la résistivité électrique - issue des tomographies de résistivités électriques (ERT) inversées par le logiciel Res2DInv - et la teneur en eau volumique enregistrée par les sondes TDR - (la position de ces mesures est située sur les stations A et B, visibles sur la figure $2 b$ ). Le nombre de données est égal à 46.

Figure 4: Comparison between the volumetric water content measured in the field on the auger holes, and the water content estimated at these points from the interpreted resistivity map.(Each point of estimated water content is calculated from the estimated values in a circle of $1 \mathrm{~m}$ diameter around the position of the auger hole).

Figure 4 : Comparaison entre la teneur en eau volumique mesurée au champ lors de la prospection à la tarière, et la teneur en eau volumique estimée en ces mêmes points à partir de la carte de résistivité interprétée (chaque point de teneur en eau estimée résulte de l'interpolation des estimations de la teneur en eau sur un cercle de $1 \mathrm{~m}$ autour de la position du point de sondage). 
Version définitive du manuscrit publié dans / Final version of the manuscript published in :

Comptes Rendus Géoscience, 2009, 341(10-11), 859-867, http://dx.doi.org/10.1016/j.crte.2009.07.011

Table 1: Synthesis of the meas

2 brackets).

Tableau 1: Synthèse des donné 4 parenthèses).

\begin{tabular}{|c|c|c|c|c|}
\hline & & & $12^{\text {th }}$ April 2006 & $1^{\text {st }}$ June 2006 \\
\hline \multicolumn{5}{|l|}{ Apparent resistivity (ohm.m) } \\
\hline V1 array & 嵌 & & $22-\mathbf{3 7}( \pm 9)-93$ & $26-58( \pm 21)-158$ \\
\hline V2 array & $\sum_{\substack{0 \\
\Phi}}$ & & $36-57( \pm 12)-127$ & $41-76( \pm 19)-154$ \\
\hline V3 array & $\stackrel{\Xi}{\Xi}$ & & $64-113( \pm 16)-203$ & $94-139( \pm 18)-225$ \\
\hline Interpreted resistivity (ohm.m) & 离 & & $15-26( \pm 4)-47$ & $26-46( \pm 12)-99$ \\
\hline Volumetric water content $(\mathrm{cm}$ & 沯 & $-3)$ & $0.23-0.28( \pm 0.01)-0.33$ & $0.16-0.24( \pm 0.02)-0.28$ \\
\hline Water potential $(|\log \mathrm{hPa}|)$ & 鸪 & & $2.83-3.29( \pm 0.14)-3.83$ & $3.29-3.79( \pm 0.24)-4.72$ \\
\hline
\end{tabular}




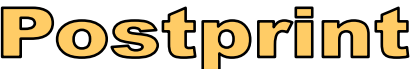

Version définitive du manuscrit publié dans / Final version of the manuscript published in :

Comptes Rendus Géoscience, 2009, 341(10-11), 859-867, http://dx.doi.org/10.1016/j.crte.2009.07.011 


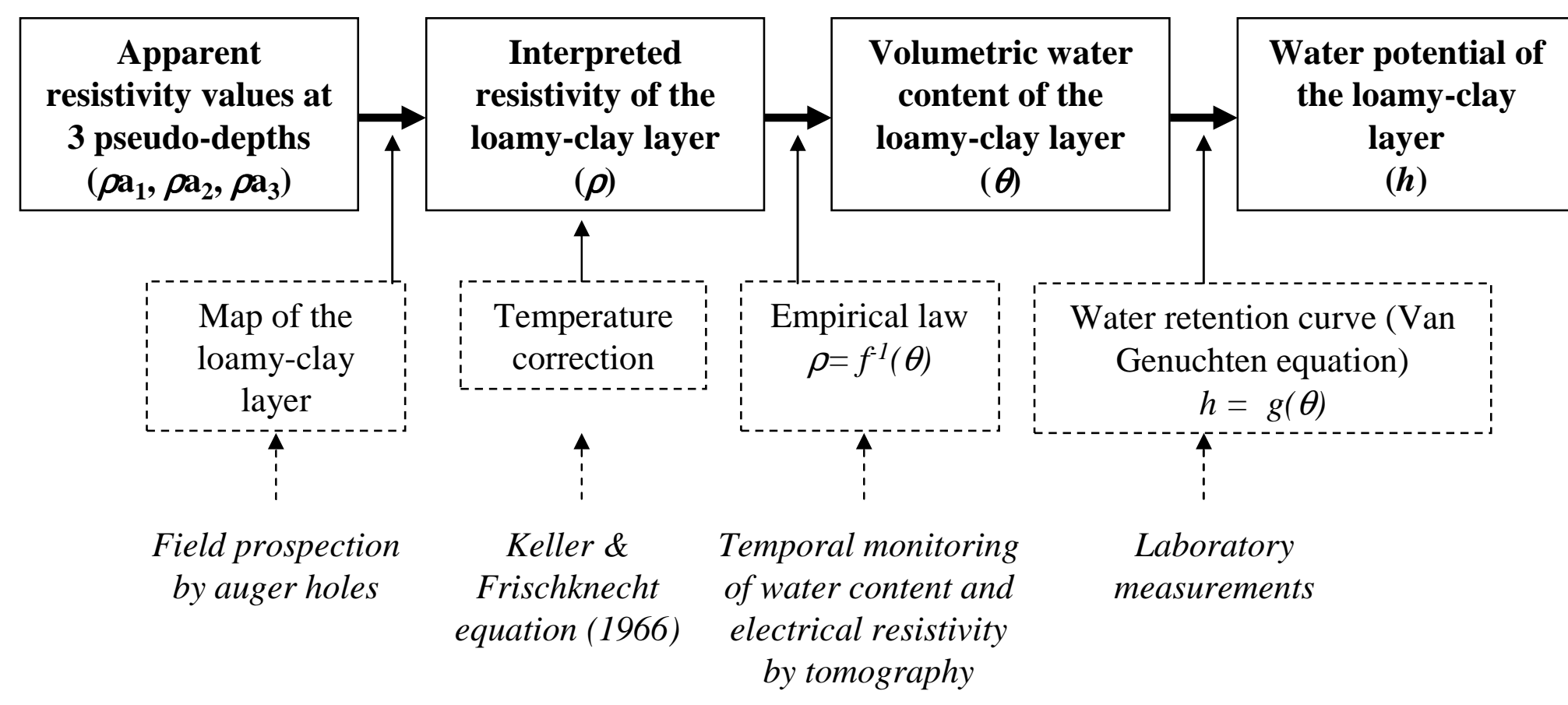




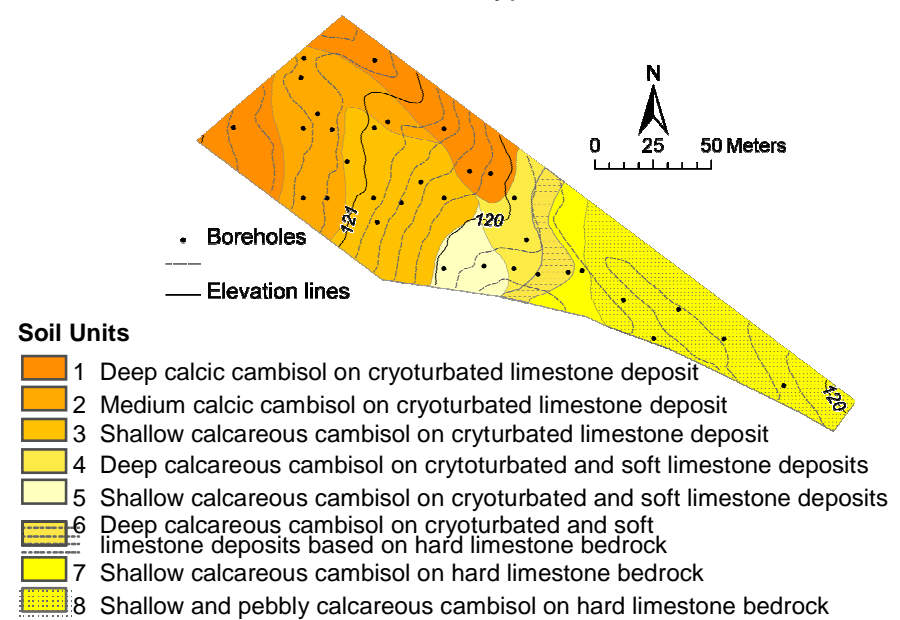

-a-

APRIL

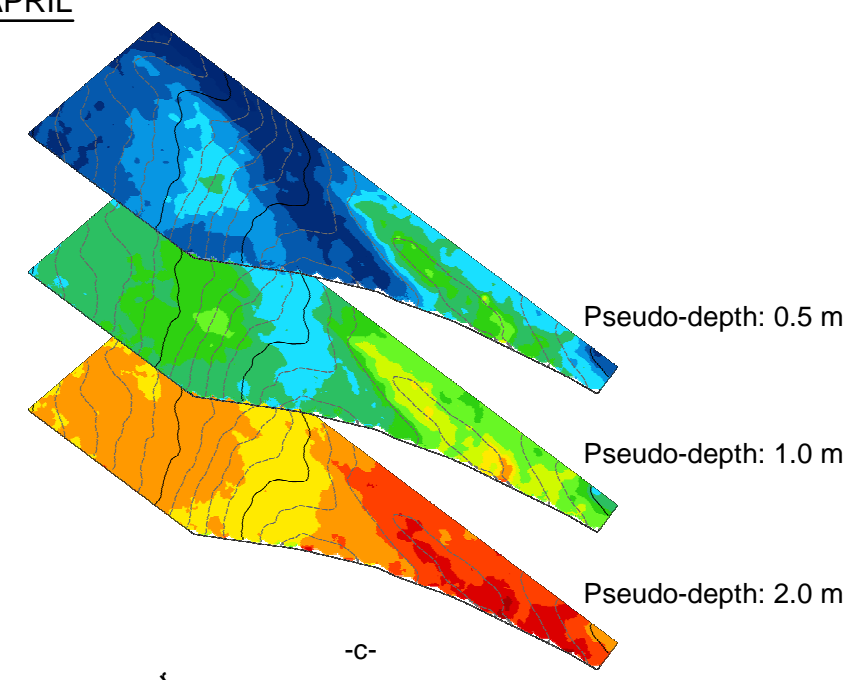

Apparent resistivity

\section{/ ohm.m}

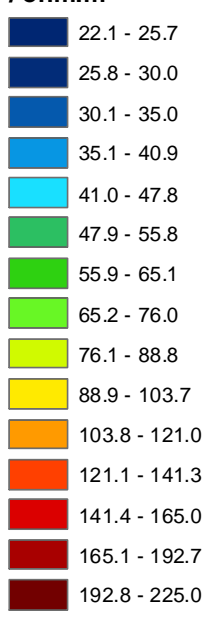

Interpreted resitvity

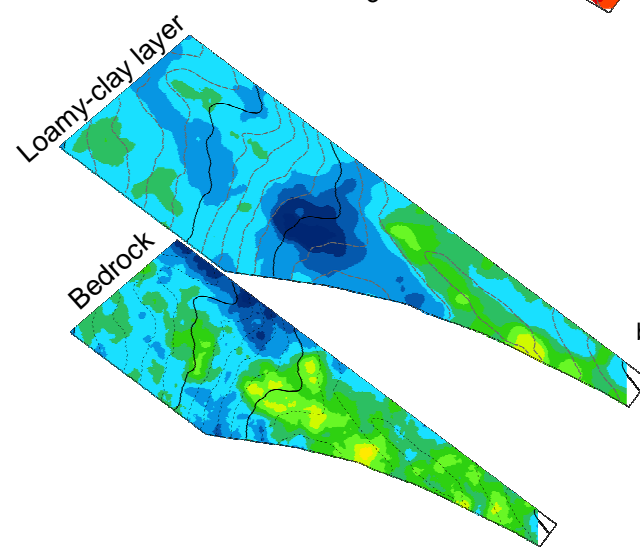

$-d-$
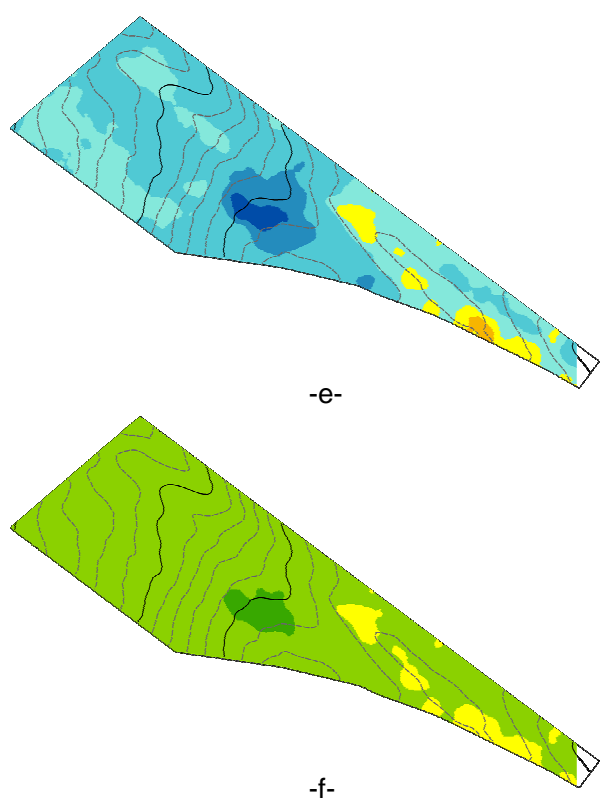

loamy clay / ohm.m

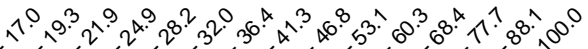

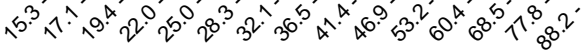

bedrock/ohm.m

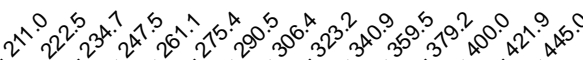

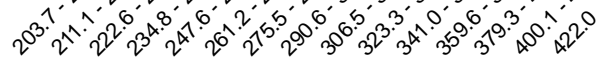

\section{Volumetric water content}

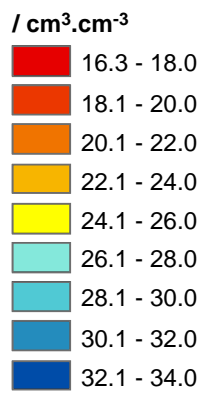

Water potential

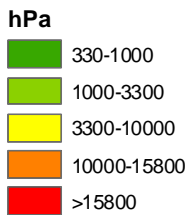

$-b-$
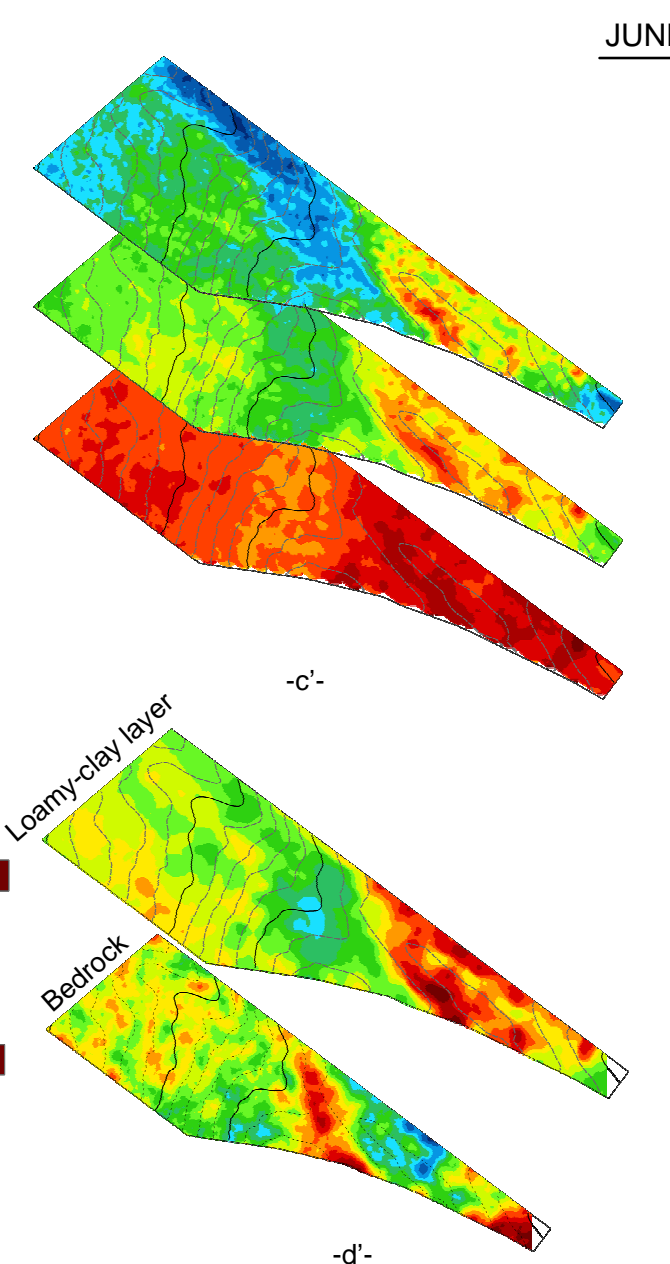

$-d^{\prime}-$

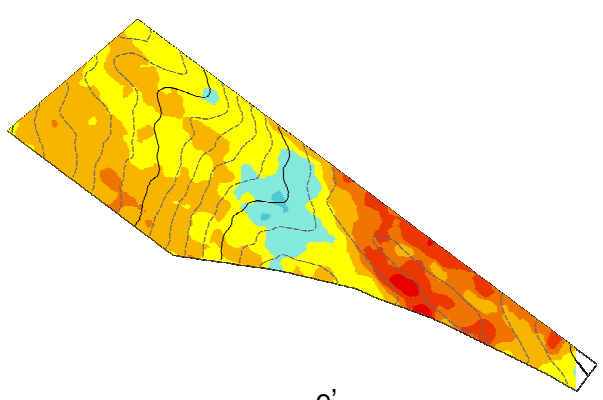

$-e-$

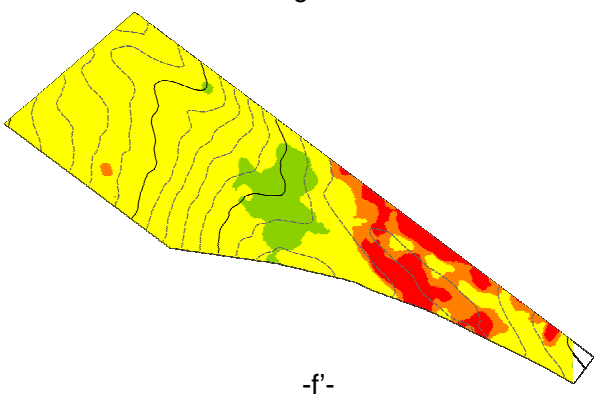

Figure 2 


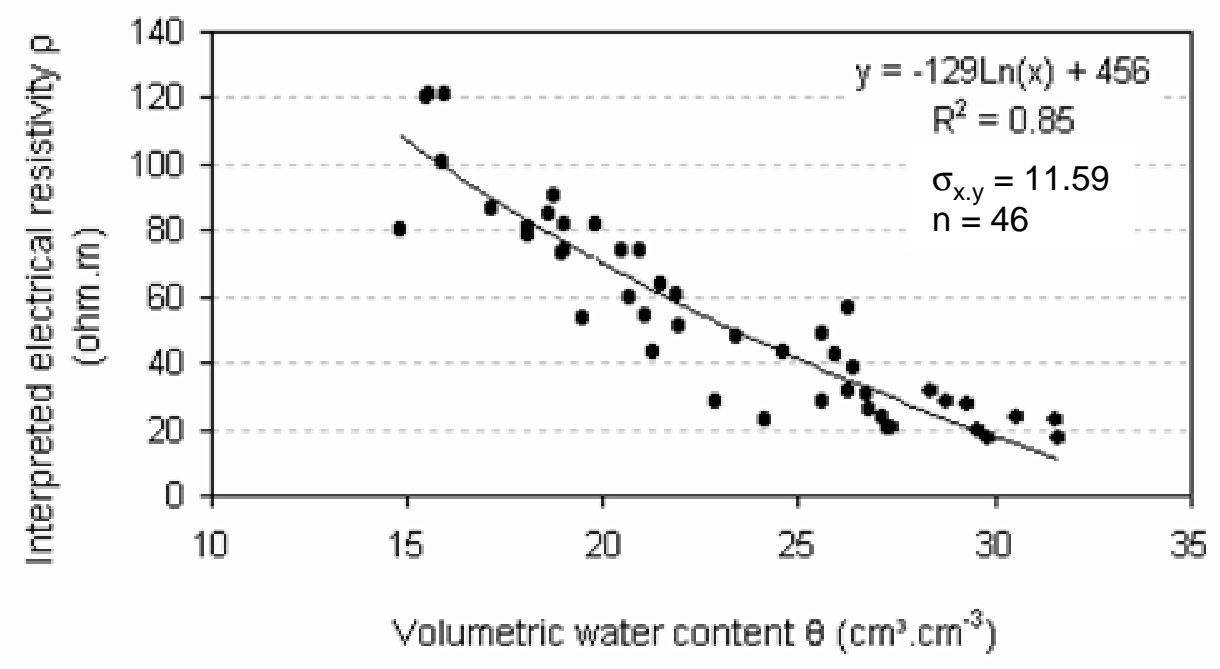

Figure 3 


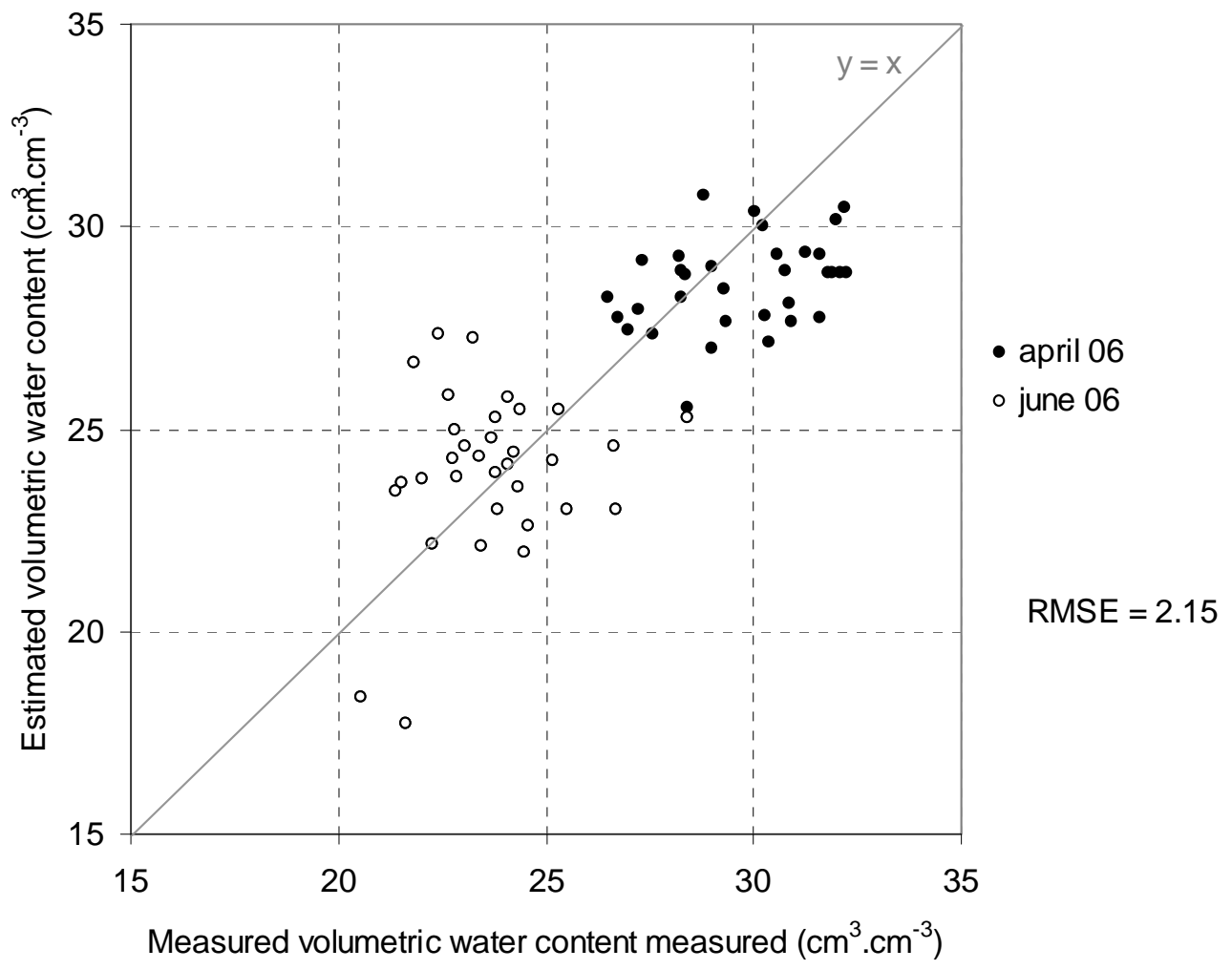

Figure 4 